\title{
OCHRATOXIN A DETERMINATION IN BEER BY IMMUNOAFFINITY COLUMN CLEAN-UP AND HIGH-PERFORMANCE LIQUID CHROMATOGRAPHY ${ }^{1}$
}

\author{
Guilherme PRADO ${ }^{2}$, Marize Silva OLIVEIRA², Eliana Pinheiro CARVALHO ${ }^{3}$, Luiz Carlos OLIVEIRA
}

LIMA $^{3}$, Thais VELOSO 2 , Leandro Augusto Ferreira SOUZA ${ }^{4}$, Ana Cristina Ferreira CARDOSO ${ }^{4}$

\section{SUMMARY}

Analyses of ochratoxin A (OTA) in domestic and imported beers were perfomed by immunoaffinity column and high - perfomance liquid chromatography (HPLC) using a fluorescence detector. Recoveries of OTA from beer samples spiked at levels from 8.0 to 800 pg/mL ranged from $81.2 \%$ to $95.0 \%$, with coefficient of variation between $0 \%$ e $11.0 \%$. Detection limit and quantification limit were $2.0 \mathrm{pg} / \mathrm{mL}$ and $8.0 \mathrm{pg} / \mathrm{mL}$, respectively. Of the total of 26 samples produced in Brazil only 6 (23\%), contained trace amounts of OTA. Of the 4 imported beers, in 2, Ireland and Germany, were detected OTA at levels of $25 \mathrm{pg} / \mathrm{mL}$ and $82 \mathrm{pg} / \mathrm{mL}$, respectively.

Keywords: ochratoxin A; beer; immunoaffinity; HPLC.

\section{RESUMO}

DETERMINAÇÃO DE OCRATOXINA A EM CERVEJA POR COLUNA DE IMUNOAFINIDADE E CROMATOGRAFIA LÍQUIDA. Análises de ocratoxina A em cervejas nacionais e importadas foram executadas por coluna de imunoafinidade e cromatografia líquida de alta eficiência (CLAE) com detetor de fluorescência. Recuperações de ocratoxina A em amostras de cervejas contaminadas em niveis de 8.0 a $800 \mathrm{pg} / \mathrm{mL}$, foram de $81,2 \%$ a $95 \%$, com coeficiente de variação entre $0 \%$ e $11 \%$. O limite de detecção e o de quantificação foram $2.0 \mathrm{pg} /$ $\mathrm{mL}$ e $8.0 \mathrm{pg} / \mathrm{mL}$, respectivamente. De um total de 26 amostras fabricadas no Brasil, somente $6(23 \%)$ apresentavam traços $(\mathrm{pg} / \mathrm{mL}) \mathrm{de}$ ocratoxina A. Das 4 amostras de cerveja importadas analisadas, em duas, Irlanda e Alemanha, foram detectadas ocratoxina A em niveis de $25 \mathrm{pg} / \mathrm{mL}$ e $82 \mathrm{pg} / \mathrm{mL}$, respectivamente.

Palavras-chave: ocratoxina A; cerveja; imunoafinidade; CLAE.

\section{1 - INTRODUCTION}

Ochratoxin A (OTA), a phenylalanyl derivative of a substituted isocoumarin, is a secondary metabolite produced by Penicillium verrucosum in temperate climates and by a number of species of Aspergillus in warmer and tropical parts of the word. The best known species of Aspergillus producing ochratoxin A is A. ochraceus [16].

OTA is nephrotoxic to all animal species studied so far and most likely to humans, who show the longest half - life time for elimination of this toxin amongst all species examined. OTA is teratogenic, immunotoxic, genetoxic, mutagenic and carcinogenic [3, 5].

The IARC (International Agency for Research on Cancer) has classified OTA as a possible carcinogen to humans (Group 2B) [8]. OTA is suspected to be involved in the Balkan Endemic Nephropathy (BEN), a fatal kidney disease occurring in some areas of south - eastern Europe and to be associated with urinary tract tumors [1, 21].

OTA has been found in human blood serum [28], in human milk [9, 14, 15] and in a wide range of commodities, including cereals, coffee, pork and poultry meat, pulses, beer, wine and grape-juice $[10,11,17$, $19,20,22,26,27,30,33]$.

\footnotetext{
${ }^{1}$ Recebido para publicação em 25/10/2001. Aceito para publicação em 25/07/2003 (000768).

. Fundação Ezequiel Dias - Núcleo de Micologia e Micotoxinas. Rua Conde Pereira Carneiro, 80. Gameleira - Belo Horizonte - MGCEP - 30510-010.E-mail: gui@funed.mg.gov.br

3. Universidade Federal de Lavras - MG. Pós-Graduação em Ciência dos Alimentos - Caixa Postal 37 - CEP - 37200-000-Lavras / MG. 4. Bolsistas do CNPq.

* A quem a correspondência deve ser enviada
}

Several countries have specific regulations for OTA with maximum permitted levels ranging from 1 to $50 \mu \mathrm{g} /$ $\mathrm{kg}$ for foods [7]. Within the Europe, tolerance levels for ochratoxin A have been suggested at $1 \mu \mathrm{g} / \mathrm{kg}$ for infant foods and at $5 \mu \mathrm{g} / \mathrm{kg}$ for cereals [6, 29]. In Brazil, no OTA levels have been officially set for foods.

There is a possibility of transmission of OTA from contaminated grains into beer. OTA does not survive the malting process and adjuncts would be expected to be the source of any OTA in commercial beer [23, 24].

Provisional estimates of Codex Alimentarius Commission, based on limited European data, suggest that beer is the fourth major source of human exposure to OTA following cereals, red wine and coffee [32]. Recently, the Italian Ministry of Health has issued a directive setting guidelines for OTA in several products, including beer, for which a maximum level of $0.2 \mu \mathrm{g} / \mathrm{L}$ has been fixed [31].

Surveys have been carried out in various countries to verify the occurrence of OTA in beer but in Brazil no data has been published. The methods currently used are often based on reversed - phase high - performance liquid chromatography with fluorescence detector $[4,12$, 13, 18, 23, 31].

The use of immunoaffinity chromatography in the clean-up step has given a strong impulse to the improvement of mycotoxin analysis, providing a number of advantages: (1) clean extracts; (2) precision and accuracy; (3) rapidity; (4) reduction of the use of dangerous solvents $[25,30]$. The main advantage of these columns seemed to be that OTA is bound specifically to the antibody and the matrix interference can be removed nearly completely [2].

The purpose of this work was investigate the occurrence of OTA in Brazilian and imported beers sold 
in food stores and supermarkets of some cities of $\mathrm{Mi}$ nas Gerais/Brazil.

\section{2 - MATERIALS AND METHODS}

\section{1 - Samples}

A total of 20 beer brands, 16 domestic and 4 imported beers, were analysed. Different bottles were collected corresponding to 30 samples. The samples were collected by the Inspection Service of Minas Gerais / Brazil, between March and July/2001. The Brazilian beers corresponding at least a five large differents companies.

Sample preparation consists in the preliminary degassing step, by sonicating beer samples for $1 \mathrm{~h}$, previously opened and cooled at $+4^{\circ} \mathrm{C}$ for $12 \mathrm{~h}$.

\section{2 - Immunoaffinity column clean-up}

The method used was described by VISCONTI, APSCALE \& CENTONZE [31]. A $10 \mathrm{~mL}$ of degassed beer were diluted with $10 \mathrm{~mL}$ of a water solution containing $1 \%$ polyethylene glicol 8000 and 5\% sodium hydrogencarbonate and filtered through Whatman GF/B glass microfibre filter. A $10 \mathrm{~mL}$ of diluted extract were cleaned up through an ochratest immunoaffinity column (Vicam L. P., USA) at a flow rate of about 1 drop per second. The column was washed with $5 \mathrm{~mL}$ of a solution containing $\mathrm{NaCl}(2.5 \%)$ and $\mathrm{NaHCO}_{3}(0.5 \%)$ followed by $5 \mathrm{~mL}$ distilled water at $1-2$ drops per second flow rate. OTA was eluted with $2 \mathrm{~mL}$ methanol and collected in a vial. The extract was evaporated to dryness under a nitrogen stream at ca. $50^{\circ} \mathrm{C}$ and reconstituted with $250 \mathrm{~mL}$ of the mobile phase. All analyses were done in duplicate.

\section{3 - Determination and confirmation of ochratoxin A}

Chromatographic experiments were performed using a Shimadzu liquid chromatography with a fluorescence detector (Shimadzu LC - 10 AD Model), $333 \mathrm{~nm}$ excitation, 460nm emission, with Shim - Pack CLC - ODS column, $5 \mu \mathrm{m}, 4,6$ x 250mm, preceded by a guard column Shim - Pack G - ODS, $5 \mu \mathrm{m}$, 4 x $10 \mathrm{~mm}$. The mobile phase (filtered and degassed) was acetonitrile : water : acetic acid (49.5:49.5:1) eluted at a flow rate of $1.0 \mathrm{~mL} / \mathrm{min}$. One hundred $\mathrm{ml}$ of the reconstituted extract were injected into the chromatographic apparatus. The retention time for OTA varied from 13.8 to $15.4 \mathrm{~min}$ over the period of the study.

Quantification of OTA was performed by measuring peak area at OTA retention time and comparing it with calibration curve, in the range $0.02-1.6 \mathrm{ng} / \mathrm{mL}$ (correlation coefficient: 0.9998)

The accuracy of the method was evaluated by the samples spiked with OTA, in duplicate, at levels of 8.0 , 40.0, 100.0, 200.0 and $800 \mathrm{pg} / \mathrm{mL}$.

The identity of OTA was confirmed by methyl ester formation after derivatization of the standards and samples extracts with $14 \% \mathrm{BF}_{3}$ in methanol [23].

\section{3 - RESULTS AND DISCUSSION}

Results of recovery experiments are showed on Table 1.The overall average recovery (mean of means) of OTA was $88.0 \%$, with minimum value at $81.2 \%$. The coefficients of variation (C.V.) were satisfactory (i.e. <20\%). The limit of detection (LOD) of the method was $2.0 \mathrm{pg} / \mathrm{mL}$, based on a signal/noise of $3: 1$. The limit of quantification (LOQ) of the method was $8.0 \mathrm{pg} / \mathrm{mL}$.

TABLE 1. Recovery in beer samples spiked with OTA standard

\begin{tabular}{cccc}
\hline $\begin{array}{c}\text { Amount added } \\
(\mathrm{pg} / \mathrm{mL})\end{array}$ & $\begin{array}{c}\text { Amount recovered } \\
(\mathrm{pg} / \mathrm{mL})\end{array}$ & $\begin{array}{c}\text { Recovery Mean } \\
(\%)\end{array}$ & $\begin{array}{c}\text { Coefficient of variation } \\
(\%)\end{array}$ \\
\hline 8.0 & 7.0 & 81.2 & 11.0 \\
& 6.0 & & \\
40.0 & 38.0 & 95.0 & 0,0 \\
& 38.0 & & \\
100.0 & 80.0 & 85.0 & 8.0 \\
& 90.0 & & 8.0 \\
200.0 & 180.0 & 85.0 & \\
& 160.0 & & 4.0 \\
800.0 & 730.0 & 94.0 & \\
& 770.0 & & \\
Mean of means & & 88.0 & \\
\hline
\end{tabular}

The chromatogram obtained for one naturally contaminated sample of beer containing $26 \mathrm{pg} / \mathrm{mL}$ of OTA, is reported in Figure 1, showing free of interfering compounds in the same retention time.

A summary of the results of the survey, not corrected for recovery, is shown in Table 2. Of the total of 26 samples of beer produced in Brazil, OTA were not found in $20(77 \%)$ beer samples and in $6(23 \%)$ contained trace amounts of OTA. OTA levels found in this study are considerably lower than the provisional tolerable weekly intake (PTWI) established previously as $0.1 \mu \mathrm{g} / \mathrm{Kg}$ body mass[21].

Although a limited number of samples of imported beers (four) has been analysed in this study, OTA levels found suggest that beer samples produced in Europe must be assessed. Some surveys using immunoaffinity column clean-up and high-performance liquid chromatography with fluorescence detection on European beers have proved this contamination with OTA. LEGARDA \& BURDASPAL [13] verified the presence of OTA in 37 of 38 Spanish beers $(97.4 \%)$ with mean value of $24 \mathrm{pg} / \mathrm{mL}$. DEGELMANN et al. [4] verified in 35 samples of German beers OTA levels in the range of $100-200 \mathrm{ng} / \mathrm{mL}$ in 9 beer samples, 21 samples contained trace amounts of OTA and in 5 samples no OTA was detectable. In 2000, VISCONTI, PASCALE \& CENTONZE [31] found OTA in different brands of beer produced in Europe and Italy. The incidence of positive samples of $46 \%(25 / 54)$ was observed with OTA concentrations ranging from 10.0 to $135 \mathrm{pg} / \mathrm{mL}$ and mean value of $23 \mathrm{pg} / \mathrm{mL}$. A survey of OTA in domestic and imported beers in Japan verified that in $93 \%(43 / 46)$ of the samples of Europe levels ranging from 1.7 to $66.2 \mathrm{rg} / \mathrm{mL}$ and mean value of $11.4 \mathrm{rg} / \mathrm{mL}$ [18]. 
(A)

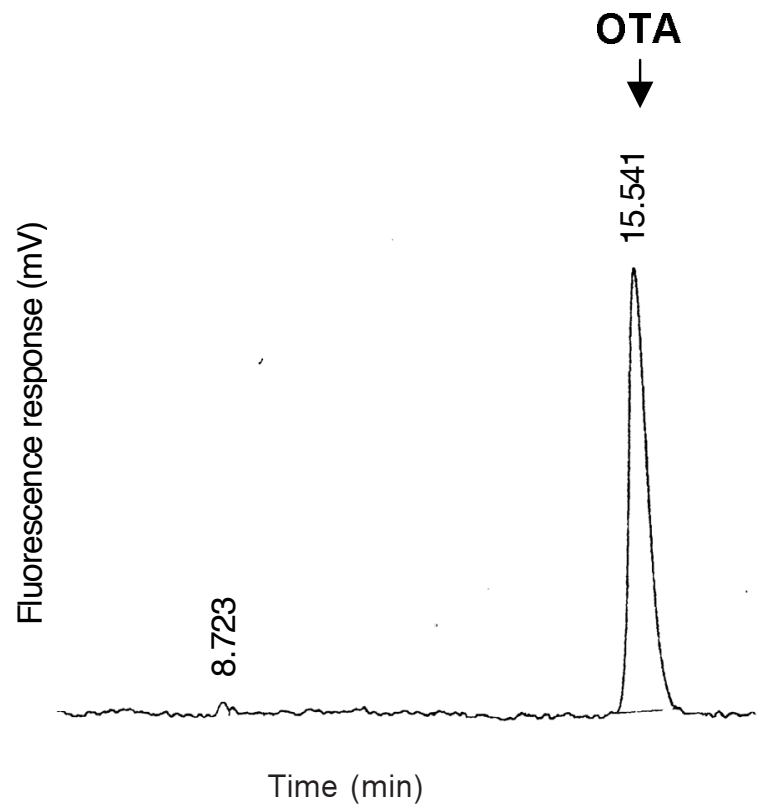

(B)

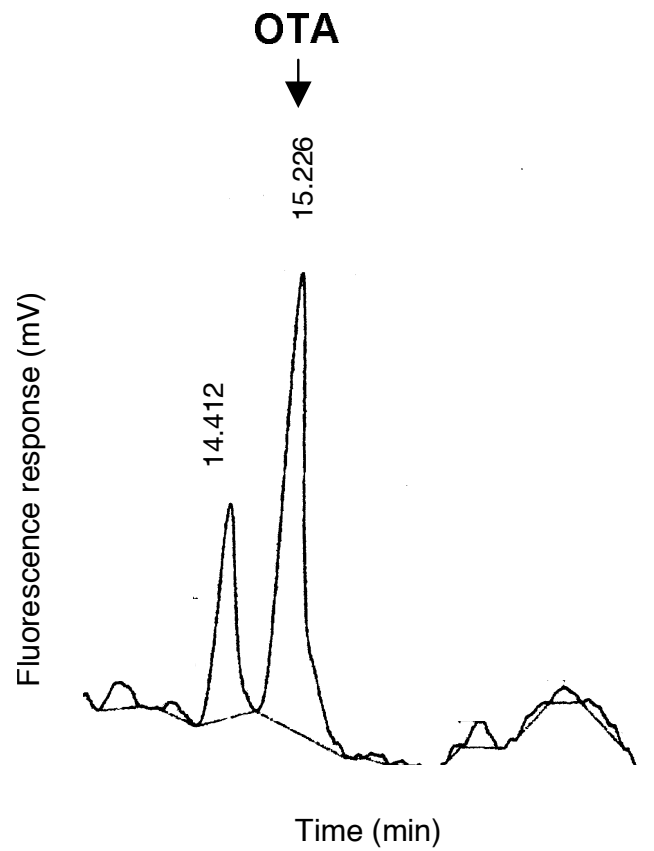

FIGURE 1. Chromatogram showing OTA peak (A) standard of OTA (62.5pg) and (B) beer naturally contaminated (26pg/mL). See Materials and Methods for chromatographic conditions.

TABLE 2. Incidence of OTA in sixteen brands of beer produced in Brazil and four imported beers from different countries

\begin{tabular}{|c|c|c|}
\hline Country & Incidence & Mean $(\mathrm{pg} / \mathrm{mL})^{1}$ \\
\hline & (Positive / Total) & \\
\hline \multicolumn{3}{|l|}{ Brazil } \\
\hline 1 & $0 / 2$ & $\mathrm{ND}^{2}$ \\
\hline 2 & $0 / 3$ & ND \\
\hline 3 & $0 / 1$ & ND \\
\hline 4 & $2 / 2$ & $>\mathrm{LOD}^{3}<\mathrm{LOQ}^{4}$ \\
\hline 5 & $0 / 1$ & ND \\
\hline 6 & $0 / 1$ & ND \\
\hline 7 & $0 / 1$ & ND \\
\hline 8 & $0 / 1$ & ND \\
\hline 9 & $2 / 2$ & $>\operatorname{LOD}<\mathrm{LOQ}$ \\
\hline 10 & $1 / 1$ & $>\operatorname{LOD}<\mathrm{LOQ}$ \\
\hline 11 & $0 / 2$ & ND \\
\hline 12 & $0 / 2$ & ND \\
\hline 13 & $0 / 1$ & ND \\
\hline 14 & $0 / 1$ & ND \\
\hline 15 & $1 / 1$ & $>$ LOD $<$ LOQ \\
\hline 16 & $0 / 4$ & ND \\
\hline Total & $6 / 26$ & $--^{5}$ \\
\hline Italy & $0 / 1$ & ND \\
\hline Ireland & $1 / 1$ & $26 \mathrm{pg} / \mathrm{mL}$ \\
\hline Mexico & $0 / 1$ & ND \\
\hline Germany & $1 / 1$ & $82 \mathrm{pg} / \mathrm{mL}$ \\
\hline
\end{tabular}

Duplicate Value ${ }^{2}$ Not Detected ${ }^{3}$ Limit of Detection: $2.0 \mathrm{pg} / \mathrm{mL}$

\section{4 - CONCLUSIONS}

The results of this study suggest that beer produced in Brazil presents no risk by human exposure to OTA through its consumption.
Surveys on the incidence of OTA in imported beer are recommended.

\section{5 - REFERENCES}

[1] CAstegnaro, M.; Plèstina, R.; Dirheimer, G.; CHERNOZEMSKY, I. N.; BARTSCH, H. (Eds.), Mycotoxins, Endemic Nephropathy and Urinary Tract Tumours, IARC Scientific Publication. No. 115, International Agency for Research on Cancer, Lyon, 1991.

[2] CASTEllari, M. ; FABbRI, S. ; FABIANI, A ; AMATI, A. ; GALASSI, S. Comparison of different immunoaffinity clean-up procedures for high-performance liquid chromatographic analysis of ochratoxin A in wines. J. Chromatogr. A, v. 888, p. 129-136, 2000.

[3] CREPPY, E.E. Human ochratoxicosis. J. Toxic. Toxin Reviews, v. 18, p. 277-293, 1999.

[4] Degelmann, P.; BeCKer, M.; HeRderiCH, M.; HUMPF, H. U. Determination of ochratoxin A in beer by high - performance liquid chromatography. Chromatogr., v. 49, n. 9/10, p. 543-546, 1999.

[5] DIRHEIMER, G. Mechanistic approaches to ochratoxin toxicity. Food. Addit. Contam., v. 13, p. 45-48, 1996.

[6] EGMOND, H.P.V. Analytical methodology and regulations for ochratoxin A. Food Addit. Contam. , v. 13, p. 1113, 1996.

[7] FOOD AND AGRICULTURAL ORGANIZATION OF THE UNITED NATIONS. Worldwide regulations for mycotoxins. 1995. A Compedium. n. 64, 45 p. Rome, 1996.

[8] INTERNATIONAL AGENCY FOR RESEARCH ON CANCER. Monographs on the Evaluation of Carcinogenic Risks to Humans, Some Naturally Occurring Substances: Food Items and Constituents, Heterocyclic Aromatic Amines and Mycotoxins, v.56, IARC, Lyon, p. 489-521, 1993. 
[9] JONSYN, F.E.; MAXWELL, S.M.; HENDRICKSE, R.G. Ochratoxin A and aflatoxins in breast milk samples from Sierra Leone. Mycopath., v. 131, p. 121-126, 1995.

[10] JORGENSEN, K.; RASMUSSEN, G.; THORUP, I. Ochratoxin A in Danish cereals 1986 - 1992 and daily intake by the Danish population. Food Addit. Contam., v. 13, n. 1, p. 95-104, 1996.

[11] JORGENSEN, K. Survey of pork, poultry, coffee, beer and pulses for ochratoxin A. Food Addit. Contam., v. 15, n. 5, p. 550 - 554, 1998.

[12] JORNET, D.; BUSTO, O. ; GUASCH, J. Solid - phase extraction applied to the determination of ochratoxin A in wines by reversed - phase high-performance liquid chromatography. J. Chromatogr. A, v. 882, p. 29-35, 2000.

[13] LEgARDA, T. M. \& BURDASPAL, P. A. Ochratoxina A em cervezas elaboradas em Espanã y em otros paises europeos. Alimentaria, v. 35, n. 291, p. 115-122, 1998.

[14] MICCO, C.; MIRAGLIA, M.; BRERA, C.; CORNELI, S.; AMBRUZZI, A. Evaluation of ochratoxin A level in human milk in Italy. Food. Addit. Contam., v. 12, n. 3, p. 351-354, 1995.

[15] MIRAGLIA, M.; DOMINICIS, A.; BRERA, C.; CORNELI, S.; CAVA, E.; MENGHETTI, E.; MIRAGLIA, E. Ochratoxin A in human milk and related food samples: an exposure assessment. Natural Toxins, v.3, p. 436444, 1995.

[16] Moss,M.O. Mode of formation of ochratoxin A. Food Addit. Contam., v. 13, Supplement, p. 5-9, 1996.

[17] NAKAJIMA, M.; TSUBOUCHI, H.; MiYABE, M.; UENO, $\mathrm{Y}$. Survey of Aflatoxin $\mathrm{B}_{1}$ and Ochratoxin $\mathrm{A}$ in Commercial Green Coffee Beans by High-performance Liquid Chromatography Linked with Immunoaffinity Chromatography. Food Agric. Immun., v. 9, p. 77-83, 1997.

[18] NAKAJIMA, M.; TSUBOUCHI, H.; MIYABE, M. A survey of ochratoxin A and aflatoxins in domestic and imported beers in Japan by immunoaffinity and liquid chromatography. J. AOAC Int., v. 82, n.4, p. 897-902, 1999.

[19] PATEl, S.; HAZEl, C. M.; Winterton, A. G. M.; MORTBY, E. Survey of ethnic foods for mycotoxins. Food Addit. Contam., v. 13. n. 7, p. 833-841, 1996.

[20] PATEL, S.; HAZEL, C. M.; WINTERTON, A. G. M.; GLEADLE, A. E. Survey of ochratoxin A in UK retail coffees. Food Addit. Contam., v.14, n. 3, p. 217-222, 1997.

[21] PLÈstinA, R. Nephrotoxicity of ochratoxin A. Food Addit. Contam., v.13, p. 49-50, 1996.

[22] PRADO, G.; OLIVEIRA, M. S.; ABRANTES, F. M.; SANTOS, L. G.; VELOSO, T.; BARROSO, R. E. S. Incidência de ocratoxina A em café torrado e moído em café solúvel consumido na cidade de Belo Horizonte, MG. Ciênc. Tecnol. Aliment., v. 20, n. 2, p. $192-196,2000$.
[23] SCOTT, P.M. \& KANHERE, S. R. Determination of ochratoxin A in beer. Food Addit. Contam., v.12, n. 4, p. 591-598, 1995.

[24] SCOTT, P. M. Mycotoxins transmitted into beer from contaminated grains during brewing. J. AOAC Int. , v. 79, n.4, p. 875-882, 1996.

[25] SCOTT, P. M. \& TRUCKSESS, M. W. Application of immunoaffinity columns to mycotoxin analysis. J. AOAC Int. , v. 80, n. 5, p. 941-949, 1997.

[26] STEGEN, G.; JÖRISSEN, U.; PITTET, A.; SACCON, M.; STEINER, W.; VINCENZI, M.; WINKLER, M.; ZAPP, J.; SCHLATTER, C. Screening of European coffee final products for occurrence of ochratoxin A (OTA). Food Addit. Contam., v. 14, n. 3, p. 211-216, 1997.

[27] TRUCKSESS, M. W.; GILER, J.; YOUNG, K.; WHITE, K. D.; PAGE, S. W. Determination and survey of ochratoxin A in wheat, barley, and coffee - 1997. J AOAC Int., v. 82, n. 1, p. 85-89, 1999

[28] UENO, Y.; MAKI, S.; LIN, J.; FURUYA, M.; SUGIURA, Y.; KAWAMURA, O. A 4 - year study of plasma ochratoxin $A$ in a selected population in Tokyo by immunoassay and immunoaffinity columnlinked HPLC. Food Chem. Toxic., v. 36, p. 445449, 1998.

[29] VERARDI, G. \& ROSNER, H. Some reflections on establishing a community legislation on mycotoxins. Natural Toxins, v. 3, p. 337-340, 1995.

[30] VISCONTI, A.; PASCAlE, M.; CEnTONZE, G. Determination of ochratoxin $A$ in wine by means of immunoaffinity column clean-up and high-performance liquid chromatography. J. Chromatogr., v. 864, p. 89$101,1999$.

[31] VISCONTI, A; PASCALE, M.; CENTOZE, G. Determination of ochratoxin $\mathrm{A}$ in domestic and imported beers in Italy by immunoaffinity clean - up and liquid chromatography. J. Chromatogr. A, v.888, p. 321-326, 2000.

[32] WALKER, R. Presented at the $3^{\text {rd }}$ Joint FAO / UNEP International Conference on Mycotoxins, Tunis, $3-6$ March, 1999. Apud: VISCONTI, A; PASCALE, M.; CENTONZE, G. Determination of ochratoxin A in domestic and imported beers in Italy by immunoaffinity clean - up and liquid chromatography. J. Chromatogr. A, v. 888, p. 321-326, 2000.

[33] ZIMMERLI, B. \& DICK, R. Ochratoxin A in table wine and grape-juice: occurrence and risk assessment. Food Addit. Contam., v. 13, n. 6, p. 655 - 668, 1996.

\section{6 - ACKNOWLEDGEMENTS}

The authors wish to thank the CNPq and Health Ministry for the financial support. 